\title{
Dystocia due to Hydrocephalic Fetus in a Jersey Crossbred Cow
}

\author{
M. Selvaraju, N. Parthasarathy, V. Varudharajan*, S. Prakash and K. Ravikumar \\ Department of Veterinary Gynaecology and Obstetrics \\ Veterinary College and Research Institute, Namakkal - 637002 \\ Tamil Nadu Veterinary and Animal Sciences University, Chennai - 600 051, India \\ *Corresponding author
}

A B S T R A C T

\section{Ke y w o r ds \\ Dystocia, Fetal hydrocephalus, Jersey crossbred cow \\ Article Info \\ Accepted: \\ 18 May 2020 \\ Available Online: \\ 10 June 2020}

\section{Introduction}

Hydrocephalus has been encountered as an infrequent congenital anomaly in mammals causing fetal dystocia (McEntee, 1990). Hydrocephalus involves swelling of the cranium due to accumulation of fluid, which may be in the ventricular system or between the brain and the dura. In more severe cases there is marked thinning of the cranial bones (Arthur, 1975). Hydrocephalous results due to disturbance in normal flow of CSF and its reabsorption. CSF is produced primarily by the choroid plexus and by secondary extrachoroidal sites inside the brain (Ferris $e t$ al., 2011). As per Chhetri et al., (2018) and
Roberts (1971) a simple autosomal recessive gene and autosomal dominant gene with incomplete penetrance (Leipold and Dennis, 1986) have been reported to be linked with hydrocephalus in cattle. The condition could also be inherited with coexisting hypovitaminosis-A (Jubb and Kennedy, 1970). It affects all species of animals and is seen most commonly in pigs, puppies and calves. In more severe form of hydrocephalus there is marked thinning of the cranial bones (Noakes et al., 2009). The condition is well documented in cattle (Sharda and Ingole, 2002, Purohit et al., 2006; Jana and Ghosh, 2010; Murugan et al., 2014), Kangayam breed (Prakash et al., 2016), mare (Ferris et al., 
2011; Kumar et al., 2010), buffalo (Bugalia et al., 1990; Kumaresan et al., 2003) and pig (Arthur, 1975). The present case reports the successful management of dystocia due to live fetal hydrocephalus in a Jersey crossbred cow.

\section{Case history and clinical observations}

A Jersey crossbred cow on its fourth parity was presented to Veterinary Clinical Complex, Veterinary College and Research Institute, Namakkal with an anamnesis of full term pregnant, rupture of water bag with difficulty in parturition. General clinical examination revealed that the animal was in sternal recumbency with respiratory distress and continuous straining. Vaginal examination revealed that the fetus was in anterior-longitudinal presentation (P1), dorsosacral position (P2) and head resting on the forelimb towards the birth canal (P3). Palpation of the fetus showed that the fetal head was abnormal and the fetus reflexes present.

\section{Diagnosis and clinical management}

Based on the anamnesis, clinical and vaginal examination the case was diagnosed as dystocia due to fetal hydrocephalus. The animal was cast and placed on the hind quarter elevator and by traction a live female fetus was delivered. Examination of the fetus revealed dome shaped head (Fig. 1). Radiographic examination revealed fluid accumulation in the ventricular part of the cranium (Fig. 2). Ultrasonographic examination of fetal head revealed fluid filled cranium. After a day of birth, the fetus died and post-mortem examination revealed fluid accumulation in the ventricles of brain (Fig 3) and hence the case was confirmed as dystocia due to fetal hydrocephalus. Karyotyping of the fetus revealed no chromosomal abnormality (Fig 4). The dam was administered with Inj. Enrofloxacin @ $5 \mathrm{mg} /$ $\mathrm{kg}$ b.wt i/m, Inj. Calcium Borogluconate 450 $\mathrm{ml} \mathrm{i/v,} \mathrm{Inj.} \mathrm{Oxytocin} 30 \mathrm{IU} \mathrm{i} / \mathrm{v}$. The animal recovered uneventfully.

\section{Results and Discussion}

Hydrocephalus is a dropsical condition with accumulation of fluid as a result of an imbalance between the formation and drainage of cerebrospinal fluid (CSF) either in ventricular system or subarachnoid space characterized by marked enlargement of cranium (Noakes et al., 2009). The affected animals are either born dead or die shortly after birth. The calves born alive show signs of cerebral inhibition such as depression, weakness, dropsy ears and head, blindness, recumbency and convulsion (Whitlock, 2010). The infection of the fetus causes either excessive production of cerebrospinal fluid or damage to the outflow tract of the cerebrospinal fluid resulting in progressive enlargement of the fetal head with increased fluid pressure within the brain and malformation of the brain and skull (Leaold $e t$ al., 1974). In more severe cases there is marked thinning of the cranial bones (Arthur, 1975). Hydrocephalous results due to disturbance in normal flow of CSF and its reabsorption. CSF is produced primarily by the choroid plexus and by secondary extrachoroidal sites inside the brain (Ferris $e t$ al., 2011). Severe form of hydrocephalus results in dystocia and that cannot be relieved by mutation and forced traction. The excessive bony enlargement of cranium may require fetotomy (Roberts, 1971). Chhetri et al., 2018reported live fetal hydrocephalus in a crossbred cow managed by forced traction, similarly this case with dystocia due to live fetal hydrocephalus was delivered by forced traction. 


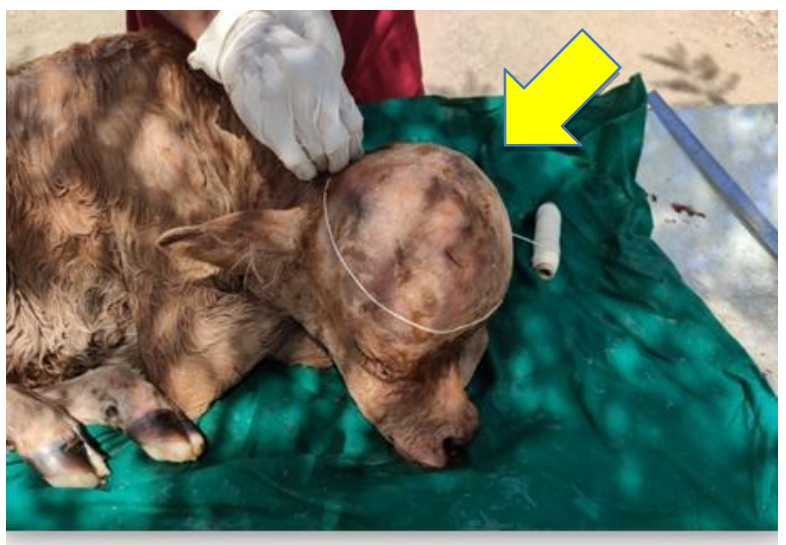

Fig.1 Dome shaped fetal head

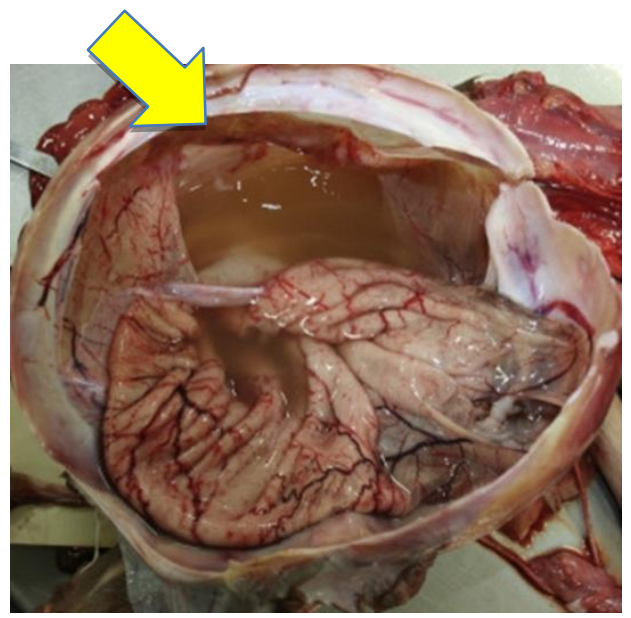

Fig.3 Post mortem examination of the fetus revealed fluid accumulation in the ventricles of the brain

\section{References}

Arthur, G.H. 1975. Veterinary reproduction and obstetrics. Fourth edition. Bailliere Tindall, Pp. 115-116.

Bugalia, N.S., Chander, S., Chandolia, R.K., Verma, S.K., Singh, P. and Sharma, O,K. 1990. Monstrosities in cows and buffaloes. Indian Veterinary Journal. 67: 1042-43.

Chhetri, B., Kalita, M.K., Deka, N. and Das,

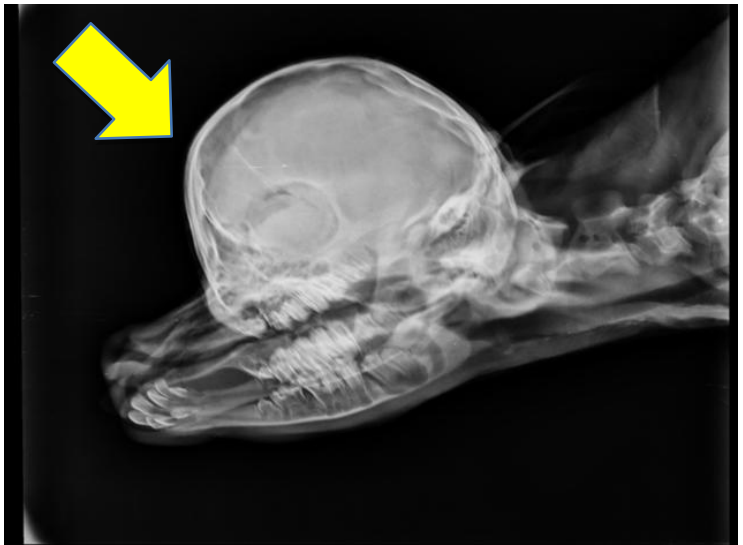

Fig.2 Radiographic view revealed fluid accumulation in the ventricles of the brain

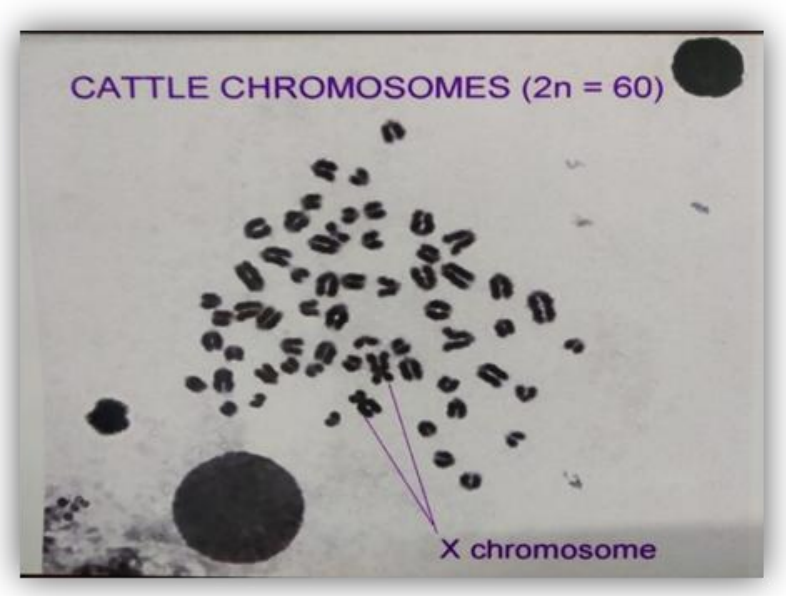

Fig.4 Karyotyping revealed no chromosomal abnormality

A. 2018. Management of live hydrocephalus calf with dystocia in indigenous cow. Int. J. Chem. Studies, 6(3): 3254-3255.

Ferris, R.A., Sonnis, J., Webb, B., Lindholm, A. and Hassel, D. 2011. Hydrocephalus in an American miniature horse foal: A case Report and Review. Journal of Equine Veterinary Science. 31: 611614.

Jana, D. and Ghosh, M. 2010. Congenital 
internal hydrocephalus in a new born cow calf. Indian J Anim. Reprod. 31:6364.

Jubb, K.V.F. and Kennedy, P.C. 1970. Pathology of Domestic Animals.2nd Edn. Academic Press, New York.568569.

Kumar, A., Ghuman, S.P.S. and Honparkhe, M. 2010. Successful delivery of hydrocephalic foal through fetotomy in a mare. Indian J Anim. Reprod. 31:8384.

Kumaresan, A., Garg, A., Mahapatra, U.S., Shankar, U. and Agarwal S.K. 2003. Dystocia due to hydrocephalus calf in a buffalo. Indian. J Anim. Reprod. 24:82.

Leaold, H.W., Mills, J.H.L. and Huston, K. 1974. Retinal dysplasia and internal hydrocephalus in a shorthorn calf. Canadian Veterinary Journal. 15(2): 3438.

Leipold, H.W. and Dennis, S,M. 1986. Congenital defects affecting bovine reproduction. In: Current Therapy in Theriogenology. D.A. Morrow (Edn) W.B. Saunders Company Philadelphia, 1105.

McEntee, K. 1990. Reproductive Pathology of Domestic Mammals, 6th edn. Academic Press, Williams and Willkins,
Baltimore, New York

Murugan, M.S., Parthiban, S., Malmarugan, S. and Raheswar, J.J. 2014. Management of dystocia due to hydrocephalus fetus in a cow. Intas polivet. 15(2): 338-339.

Noakes, D.E., Parkinson, J. and England, G.C.W. 2009. Veterinary Reproduction and Obstetrics. 9th edn. Saunders Elsevier 143.

Prakash, S., Selvaraju, M., Ravikumar, K. and Palanisamy, M. 2016. 1990. Obstetrical management of fetal hydrocephalus in a Kangayam cow. Indian Vet. J. 09: 8586.

Purohit, G.N., Gaur, M. and Sharma, A. 2006. Dystocia in Rathi cows due to congenital hydrocephalus. Indian. J Anim. Reprod. 27:98-99.

Roberts, S.J. 1971. Veterinary Obstetrics and Genital Diseases (Theriogenology) 2nd Edn. C.B.S. Publishers and Distributors, New Delhi, PP. 69.

Sharda, R. and Ingole, S.P. 2002. Congenital bilateral hydrocephalus in a jersey cow calf-a case report. Indian Veterinary Journal. 79: 965-66.

Whitlock, B.K. 2010. Heritable birth defects in cattle. Applied Reproduction Strategy Proceedings. Pp. 146-153.

\section{How to cite this article:}

Selvaraju, M., N. Parthasarathy, V. Varudharajan, S. Prakash and Ravikumar, K. 2020. Dystocia due to Hydrocephalic Fetus in a Jersey Crossbred Cow. Int.J.Curr.Microbiol.App.Sci. 9(06): 1029-1032. doi: https://doi.org/10.20546/ijcmas.2020.906.128 